\title{
Design, Fabrication, and Shakeout Testing of ATALANTE Dissolver Off-Gas Sorbent-Based Capture System
}

\section{Fuel Cycle Research \& Development}

\author{
Prepared for \\ U.S. Department of Energy \\ Material Recovery and Waste Form \\ Development Campaign \\ J. F. Walker, Jr., R. T. Jubin, \\ J. A. Jordan, and S. H. Bruffey \\ Oak Ridge National Laboratory \\ 7/31/2015 \\ FCRD-MRWFD-2015-000100 \\ ORNL/SPR-2015/352
}

Approved for public release: distribution is unlimited.

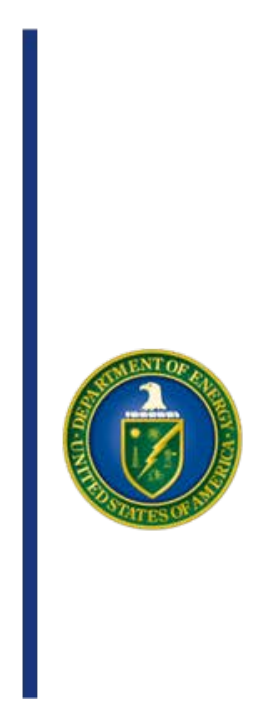




\section{DOCUMENT AVAILABILITY}

Reports produced after January 1, 1996, are generally available free via US Department of Energy (DOE) SciTech Connect.

Website http://www.osti.gov/scitech/

Reports produced before January 1, 1996, may be purchased by members of the public from the following source:

National Technical Information Service

5285 Port Royal Road

Springfield, VA 22161

Telephone 703-605-6000 (1-800-553-6847)

TDD 703-487-4639

Fax 703-605-6900

E-mail info@ntis.gov

Website http://www.ntis.gov/help/ordermethods.aspx

Reports are available to DOE employees, DOE contractors, Energy Technology Data Exchange representatives, and International Nuclear Information System representatives from the following source:

Office of Scientific and Technical Information

PO Box 62

Oak Ridge, TN 37831

Telephone 865-576-8401

Fax 865-576-5728

E-mail reports@osti.gov

Website http://www.osti.gov/contact.html

This report was prepared as an account of work sponsored by an agency of the United States Government. Neither the United States Government nor any agency thereof, nor any of their employees, makes any warranty, express or implied, or assumes any legal liability or responsibility for the accuracy, completeness, or usefulness of any information, apparatus, product, or process disclosed, or represents that its use would not infringe privately owned rights. Reference herein to any specific commercial product, process, or service by trade name, trademark, manufacturer, or otherwise, does not necessarily constitute or imply its endorsement, recommendation, or favoring by the United States Government or any agency thereof. The views and opinions of authors expressed herein do not necessarily state or reflect those of the United States Government or any agency thereof. 


\section{SUMMARY}

A sorbent-based capture system designed for integration into the existing dissolver off-gas (DOG) treatment system at the ATelier Alpha et Laboratoires pour ANalyses, Transuraniens et Etudes de retraitement (ATALANTE) facility has been successfully designed and fabricated and has undergone shakeout testing. Discussions with personnel from the ATALANTE facility provided guidance that was used for the design. All components for this system were specified, procured, and received on site at Oak Ridge National Laboratory (ORNL). The system was then fabricated and tested at ORNL to verify operation. Shakeout testing resulted in a simplified system. This system should be easily installed into the existing facility and should be straightforward to operate during future experimental testing. All parts were selected to be compatible with ATALANTE power supplies, space requirements, and the existing DOG treatment system. Additionally, the system was demonstrated to meet all of four design requirements. These include (1) a dissolver off-gas flow rate of $\leq 100 \mathrm{~L} / \mathrm{h}(1.67 \mathrm{~L} / \mathrm{min})$, (2) an external temperature of $\leq 50^{\circ} \mathrm{C}$ for all system components placed in the hot cell, (3) a sorbent bed temperature of $\sim 150^{\circ} \mathrm{C}$, and (4) a gas temperature of $\sim 150^{\circ} \mathrm{C}$ upon entry into the sorbent bed. The system will be ready for shipment and installation in the existing DOG treatment system at ATALANTE in FY 2016. 


\section{CONTENTS}

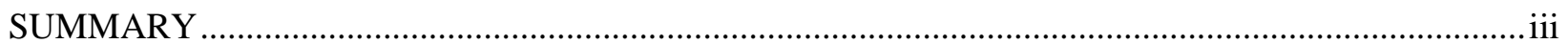

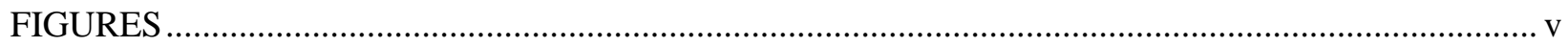

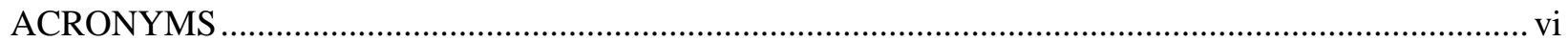

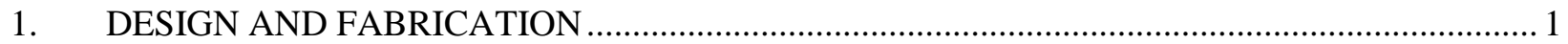

2. SHAKEOUT AND FINALIZED DESIGN OF THE SYSTEM …............................................ 7

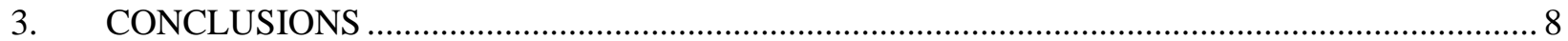




\section{FIGURES}

Figure 1: The proposed ATALANTE off-gas capture system. 1

Figure 2: Design drawing and specifications for the HTS/Amptek® heating jacket for the glass

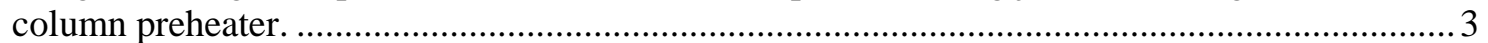

Figure 3: Design of the sorbent column for the ATALANTE off-gas capture system.............................. 4

Figure 4: Design drawing and specifications for the HTS/Amptek ${ }^{\circledR}$ heating jacket for the stainless steel sorbent column.

Figure 5: Photograph of the individual components used for fabrication of the ATALANTE DOG capture system.

Figure 6: The glass preheater and the stainless sorbent column in series. (Orange sheeting

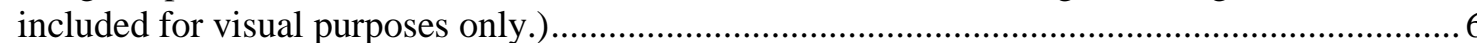

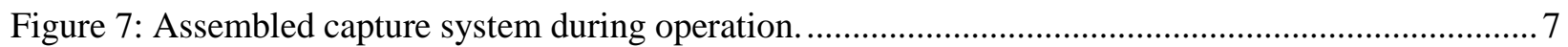

Figure 8: Finalized design for ATALANTE capture system. …............................................................. 8

Figure 9: Temperature profile of simplified capture system................................................................. 9 


\section{ACRONYMS}

ATALANTE ATelier Alpha et Laboratoires pour ANalyses, Transuraniens et Etudes de retraitement

CEA French Alternative Energies and Atomic Energy Commission (Commissariat à l'énergie atomique et aux énergies alternatives)

DOG dissolver off-gas

ORNL Oak Ridge National Laboratory 


\section{DESIGN, FABRICATION, AND SHAKEOUT TESTING OF ATALANTE DISSOLVER OFF-GAS SORBENT- BASED CAPTURE SYSTEM}

\section{DESIGN AND FABRICATION}

A small sorbent-based volatile radionuclide capture system was designed and fabricated for installation in the fuel dissolver off-gas (DOG) line located in the ATelier Alpha et Laboratoires pour ANalyses, Transuraniens et Etudes de retraitement (ATALANTE) hot cells. The ATALANTE facility is located in Marcoule, France; it was constructed by Commissariat à l'énergie atomique et aux énergies alternatives (CEA) in the late 1980s to enable research related to nuclear fuel cycle activities. A hot cell line at ATALANTE is dedicated to used nuclear fuel reprocessing and enables experimentation at different reprocessing stages, from shearing to separation and purification. This capture system was intended for placement into the existing dissolver off-gas system and was designed to be compatible with existing equipment, thus requiring minimal modification to the current DOG system. Discussions with personnel from the ATALANTE facility provided guidance for the design. The proposed design of this system is shown in Figure 1.

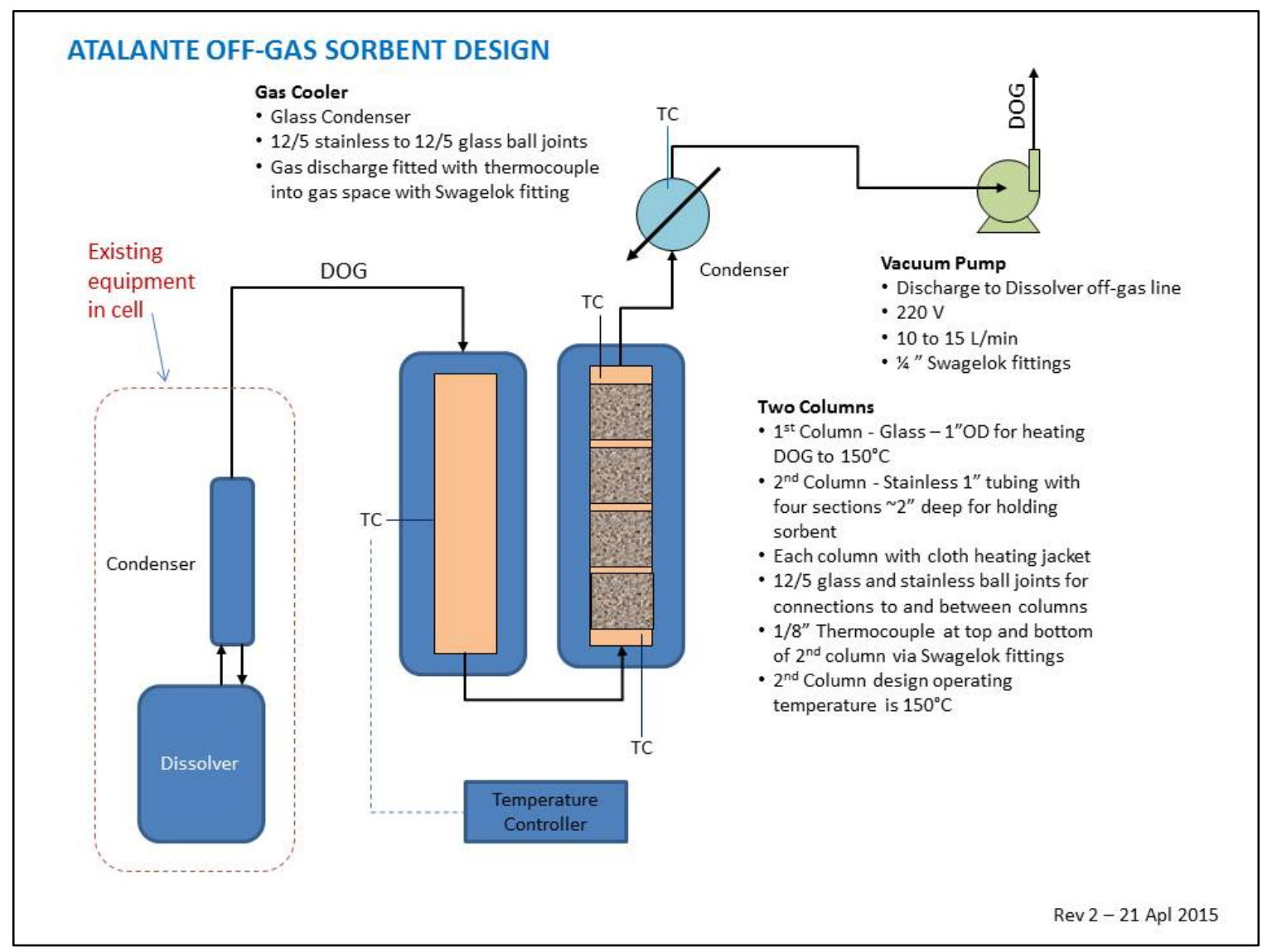

Figure 1: The proposed ATALANTE off-gas capture system. 
The entire DOG stream, which is expected to be $\sim 100 \mathrm{~L} / \mathrm{h}$, will be diverted from the ATALANTE DOG condenser, already located in the cell, into the capture system. The capture system was originally intended to consist of an $\sim 1$ in. diameter glass column filled with glass beads for heating the gas, an $\sim 1$ in. diameter stainless steel column to hold the sorbent, and a gas cooler to cool the gas exiting the sorbent bed. A vacuum pump could be provided, if necessary, to boost the flow of gas exiting the ATALANTE DOG condenser. Each of the columns and the condenser will be $\sim 13$ in. in length to meet the ATALANTE requirement that each item be no more than $15 \mathrm{in}$. long. Both of the columns were to be covered by cloth heating jackets that are designed to heat and maintain the process gas and sorbent at $150^{\circ} \mathrm{C}$. To meet ATALANTE requirements, the jackets are designed to maintain a temperature $<50^{\circ} \mathrm{C}$ on their outer surfaces. Thermocouples and a temperature controller will be used to monitor and control the temperature of the gas in the system. Power in the cell is available at 220 VAC and $2000 \mathrm{~W}$, and all electrical components in the design should be compatible with this supply source and with electrical plug and socket types already present in the cell.

The design drawing and specifications for the glass column and its heating jacket, intended to be used to preheat the gas from the ATALANTE DOG condenser before it enters the stainless steel column containing the sorbent, are shown in Figure 2. Glass was selected for this column in order to avoid the corrosion of metal by the moist iodine-bearing DOG stream. The second column was constructed of stainless steel and corrosion was not a concern because the column will be operated at high temperatures. The glass preheater column was expected to experience varied temperatures. The glass column has an outside diameter of 1.0 in. and is 11.5 in. high. Size 12/5 glass ball and socket joints are provided on the inlet and outlet of the column to mate to existing joints on the effluent from the ATALANTE DOG condenser and the inlet to the stainless sorbent column. The center-to-center distance between the glass ball joints is $13.7 \mathrm{in}$. This column is completely covered by a heating jacket provided by HTS/Amptek ${ }^{\circledR}$. When placed on the column, the total height of the unit is 15.7 in., and the total diameter is $3.0 \mathrm{in}$. Power for the jacket is single phase $220-240 \mathrm{~V}$ and $140 \mathrm{~W}$. It is provided with a type $\mathrm{K}$ thermocouple, for temperature feedback to the temperature controller, and a NEMA-5-15P plug for electrical power. Both the thermocouple and the power cord are $48 \mathrm{in}$. long. 


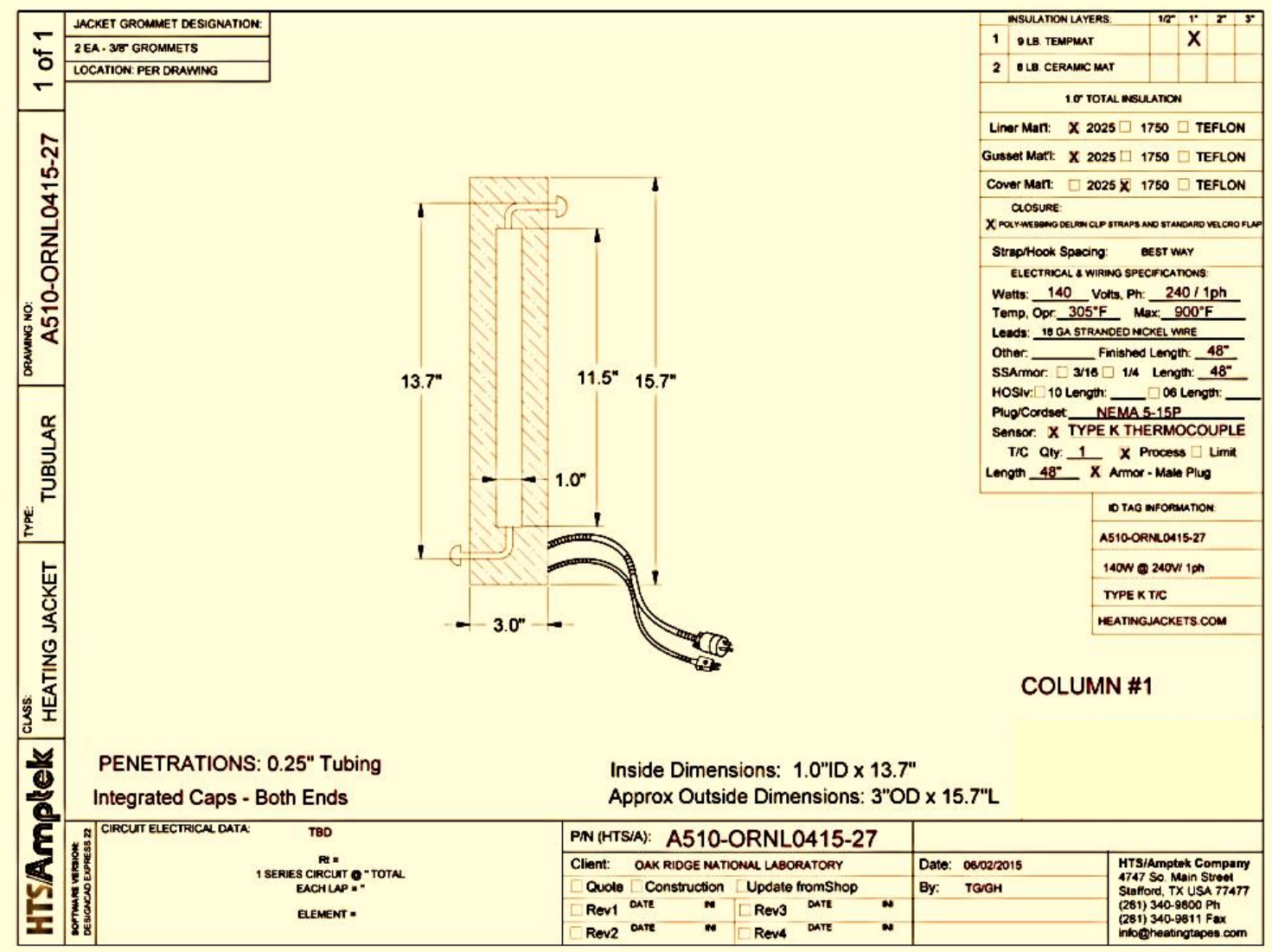

Figure 2: Design drawing and specifications for the HTS/Amptek ${ }^{\circledR}$ heating jacket for the glass column preheater.

A drawing of the stainless steel sorbent column is shown in Figure 3. The DOG will enter and exit the column through $1 / 4$ in. diameter stainless tubing that has been fitted with stainless steel size $12 / 5$ ball or socket joints. Swagelok ${ }^{\circledast}$ fittings are located at both the top and the bottom of the column for the insertion of 1/8 in. diameter thermocouples. Four removable inner sections, each with a stainless steel screen welded to the bottom, will contain the capture sorbent. The Swagelok ${ }^{\circledR}$ fitting (SS-16-UT-6) located at the top of the column is removable so that the inner sections holding the sorbent can be removed. 


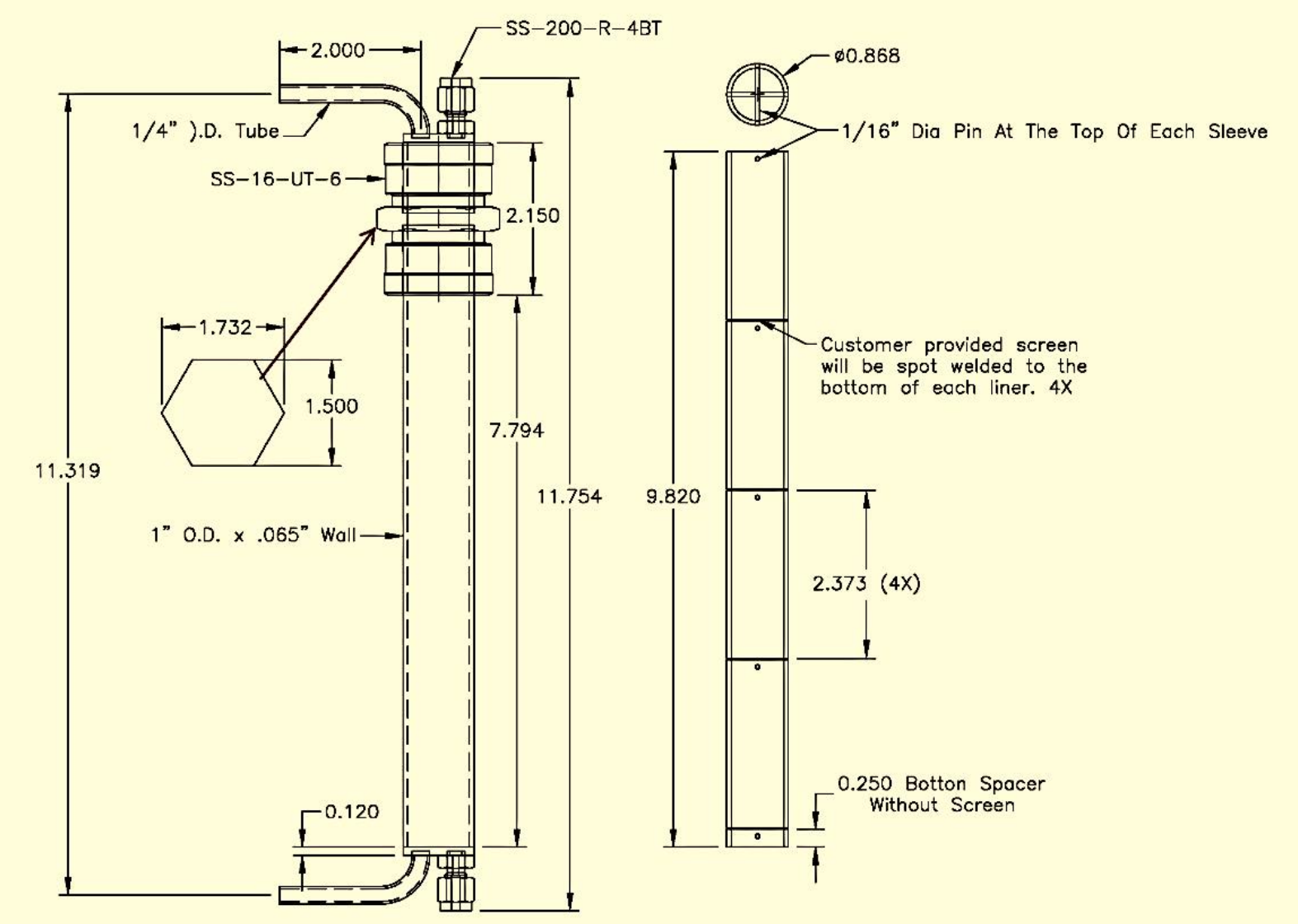

Figure 3: Design of the sorbent column for the ATALANTE off-gas capture system.

The design drawing and specifications for the heating jacket for the stainless sorbent column are shown in Figure 4. When installed on the column, the entire length of the assembly is less than 15 in. long. Openings of 1/8 in. diameter are provided at the top and bottom to accommodate thermocouples for measuring sorbent and gas temperatures. Power for the jacket is single phase 220-240 V and $65 \mathrm{~W}$. It is provided with a type $\mathrm{K}$ thermocouple, for temperature feedback to the temperature controller, and a NEMA-5-15P plug for electrical power. Both the thermocouple and the power cord are 48 in. long. 


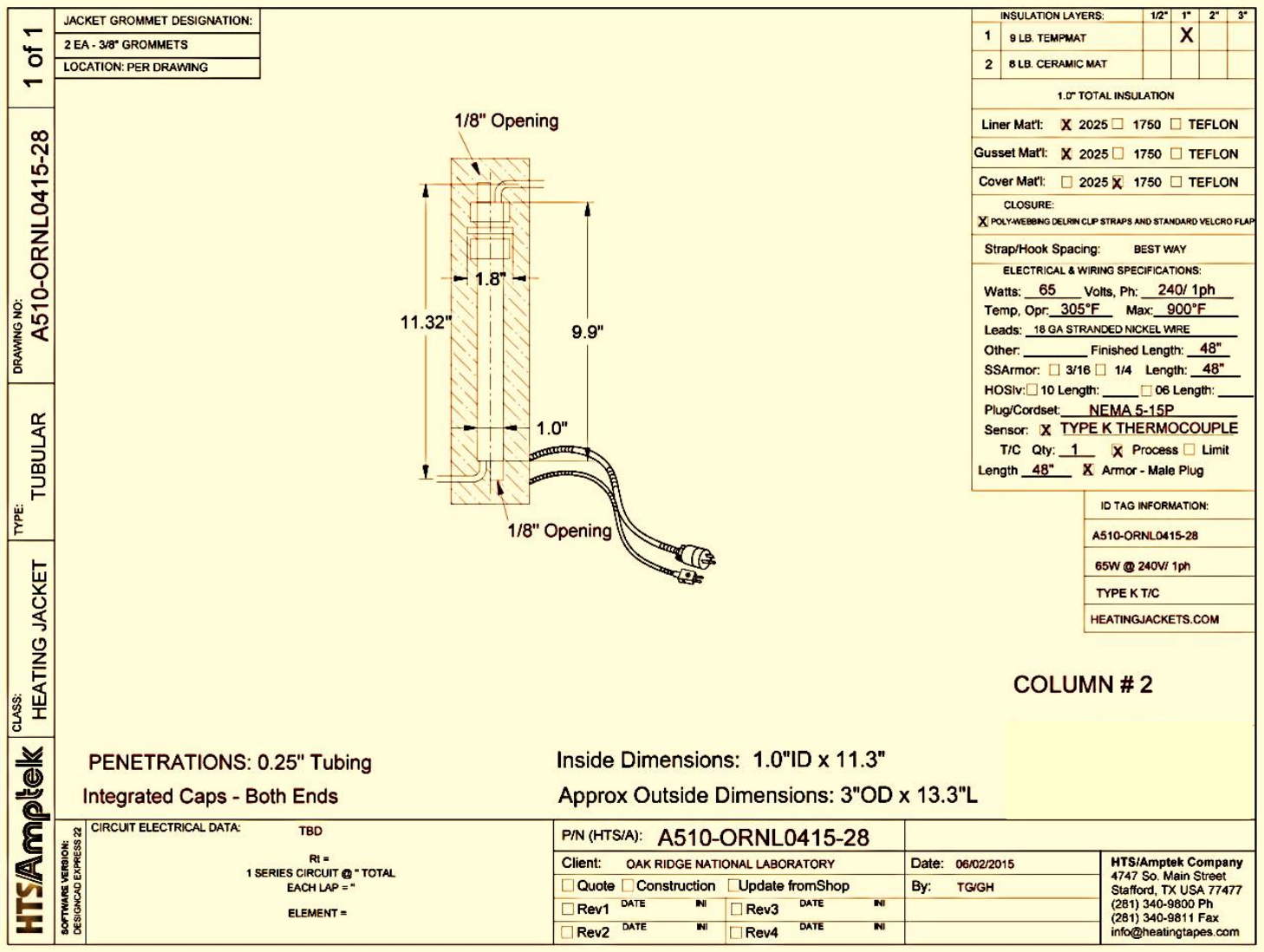

Figure 4: Design drawing and specifications for the HTS/Amptek ${ }^{\circledR}$ heating jacket for the stainless steel sorbent column.

The temperature controller for both of the heating jackets was procured from TEMPCO. It is a Model TPC30013 three zone controller which has a self-powered direct current of $2.7 \mathrm{~A}$. The third zone provides power for $240 \mathrm{~V}$ heating tapes provided by HTS/Amptek should additional heating be required at the ATALANTE facility.

A photograph of the individual components used for fabrication of the capture system is shown in Figure 5. The preheater column and sorbent column are connected in series using the 12/5 ball and socket joints as shown in Figure 6, and the system during operation is shown in Figure 7. 


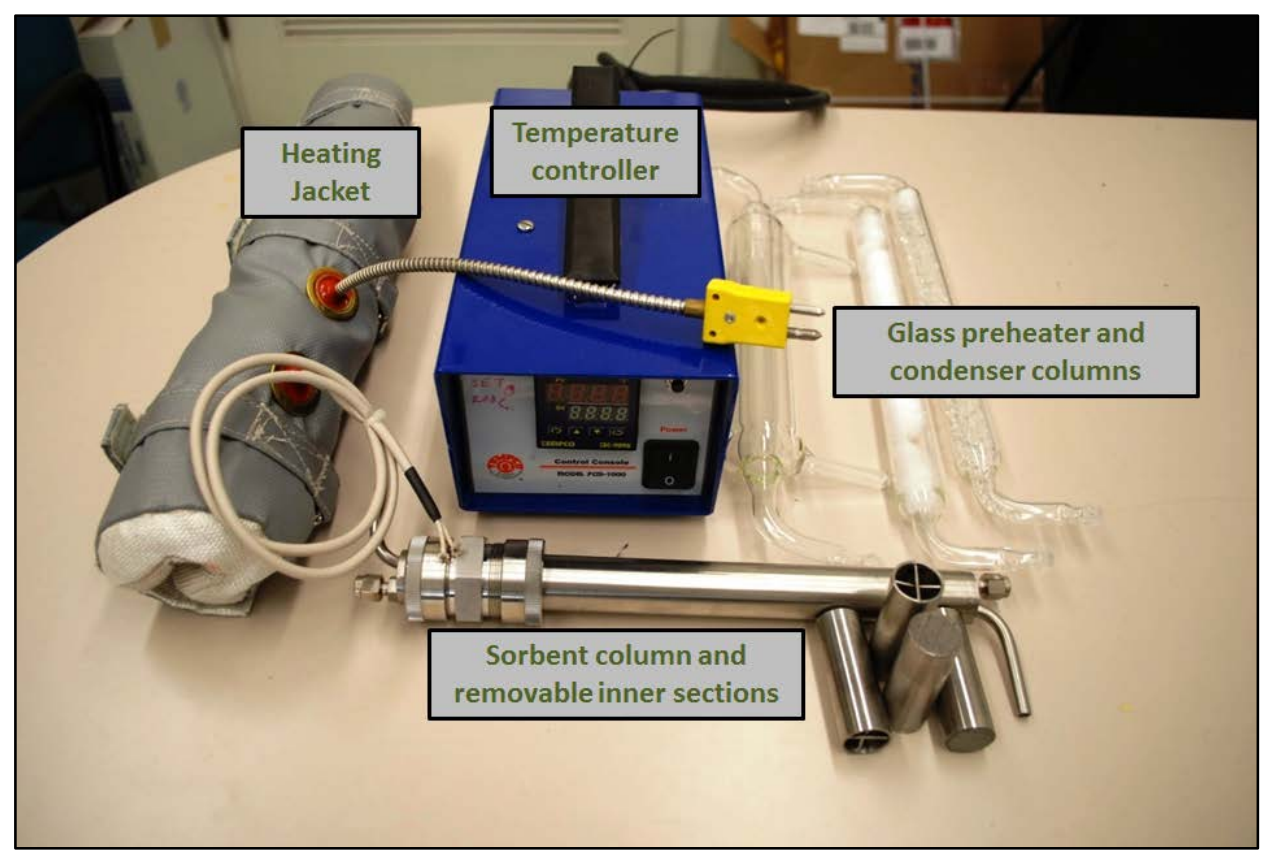

Figure 5: Photograph of the individual components used for fabrication of the ATALANTE DOG capture system.

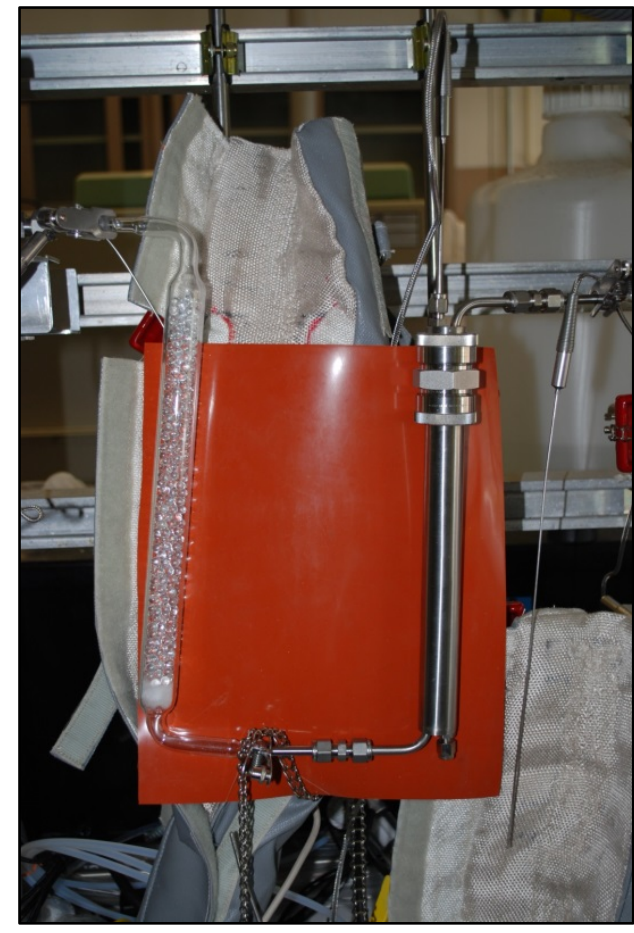

Figure 6: The glass preheater and the stainless sorbent column in series. (Orange sheeting included for visual purposes only.) 


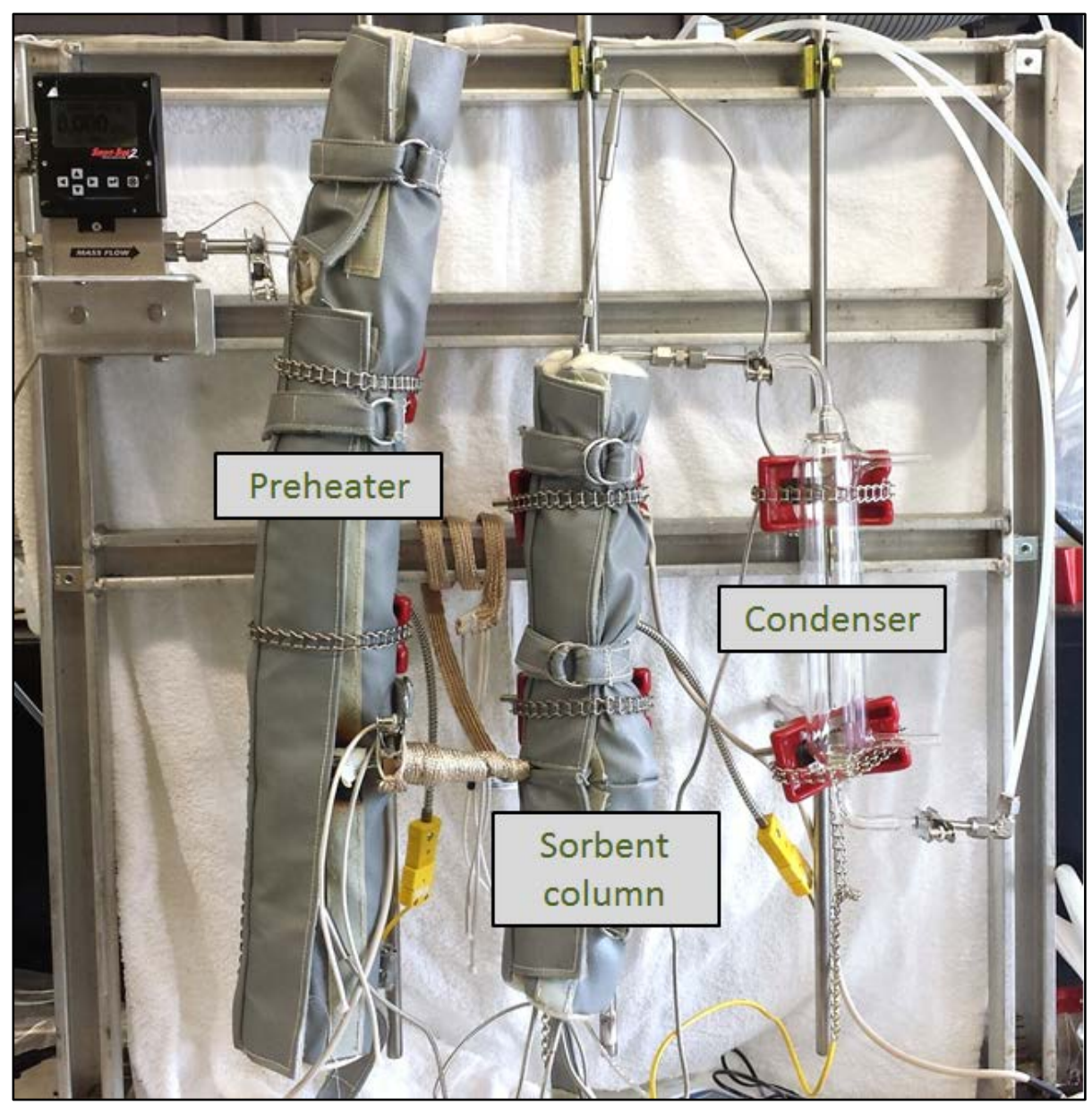

Figure 7: Assembled capture system during operation.

\section{SHAKEOUT AND FINALIZED DESIGN OF THE SYSTEM}

Shakeout testing of the capture system was conducted at ORNL to verify that the system fulfilled design requirements and was capable of operating within desired experimental parameters. The design and experimental requirements to be verified included (1) a dissolver off-gas flow rate of $\leq 100 \mathrm{~L} / \mathrm{h}$ (1.67 L/min), (2) an external temperature of $\leq 50^{\circ} \mathrm{C}$ for all system components placed in the hot cell, (3) a sorbent bed temperature of $\sim 150^{\circ} \mathrm{C}$, and (4) a gas temperature of $\sim 150^{\circ} \mathrm{C}$ upon entry into the sorbent bed. To evaluate these parameters, thermocouples were attached to the glass wall of the preheater beneath the heating jacket, to the stainless wall of the sorbent column beneath the heating jacket, and to the outer surface of both heating jackets. Thermocouples were also installed in the effluent gas stream from the sorbent column and at the approximate center of the sorbent bed. A mass flow controller was then used to control the flow of air through the system at $\sim 100 \mathrm{~L} / \mathrm{h}$ for all shakeout tests, and the temperatures of the thermocouples were measured with time.

Due to extended production lead times resulting from flooding in Texas earlier this year, the desired heating blankets were unavailable during shakeout testing. An alternative $110 \mathrm{~V}$ heating jacket and heat tape were used in their place. A $110 \mathrm{~V}$ to $220 \mathrm{~V}$ step up transformer was also procured to complete the 220 V system.

The temperature controller settings for each heating jacket were varied in an effort to achieve the desired sorbent bed and gas temperatures. Testing demonstrated that there was significant thermal loss in the 
glass ball/stainless steel socket joint connecting the preheater and sorbent bed. It was determined that the use of heat tape around the joint was required to maintain the desired gas temperature and that the use of the preheater in addition to the heat tape was redundant.

Continued discussions with ATALANTE personnel led to a determination that the condenser and vacuum pump would not be necessary to ensure compatibility with the existing DOG system. The removal of the condenser, vacuum pump, and preheater resulted in a simplified design, shown in Figure 8. As before, the redesigned system was tested to ensure it met all design and experimental requirements.

\section{ATALANTE DISSOLVER OFF-GAS TREATMENT FINAL DESIGN}

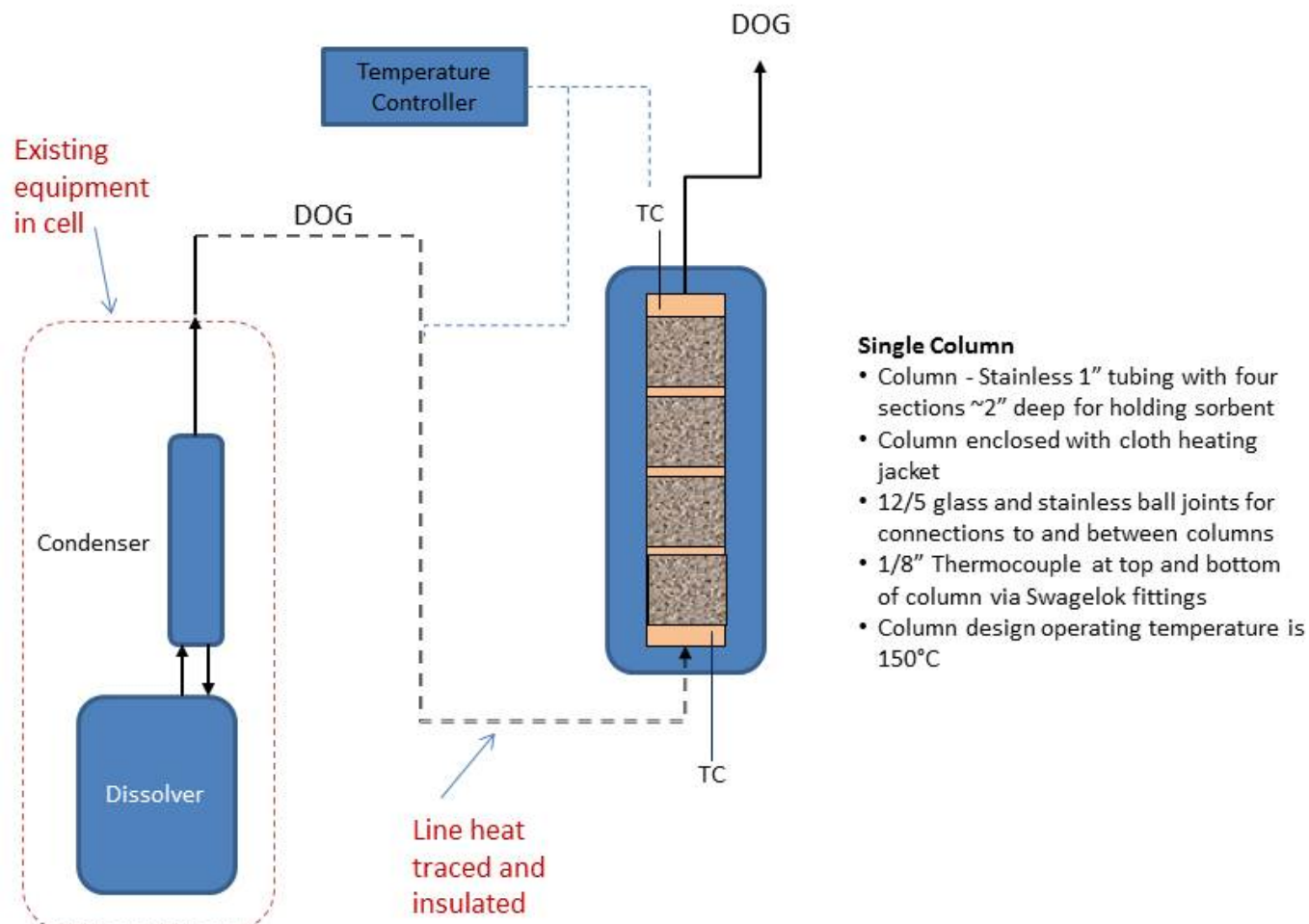

Rev 3 - 7 Jul 2015-

jfw

Figure 8: Finalized design for ATALANTE capture system.

Shakeout testing of the simplified system design produced the temperature profiles shown in Figure 9. With only the column heating blanket energized, the inlet gas temperature stabilized at $\sim 120{ }^{\circ} \mathrm{C}$ in about 2 hours. The effluent temperature rises over the next hour to $\sim 140^{\circ} \mathrm{C}$. To increase the inlet temperature to the desired 150 to $160^{\circ} \mathrm{C}$ the heat tape on the inlet line was energized activated at 175 minutes into the test. This is change is reflected in the rapid increase in inlet gas temperature at 175 min point. Both the inlet and outlet temperature reach the target 150 to $160^{\circ} \mathrm{C}$ range. 
The external temperature of the heating blanket ranged from 75 to $90^{\circ} \mathrm{C}$. This is above the $50^{\circ} \mathrm{C}$ surface temperature requirement. The addition of 1 inch thick insulation reduced the surface temperature to $<35^{\circ} \mathrm{C}$.

Additional tests with the HTS/Amptek blankets will be conducted upon their delivery to ORNL.

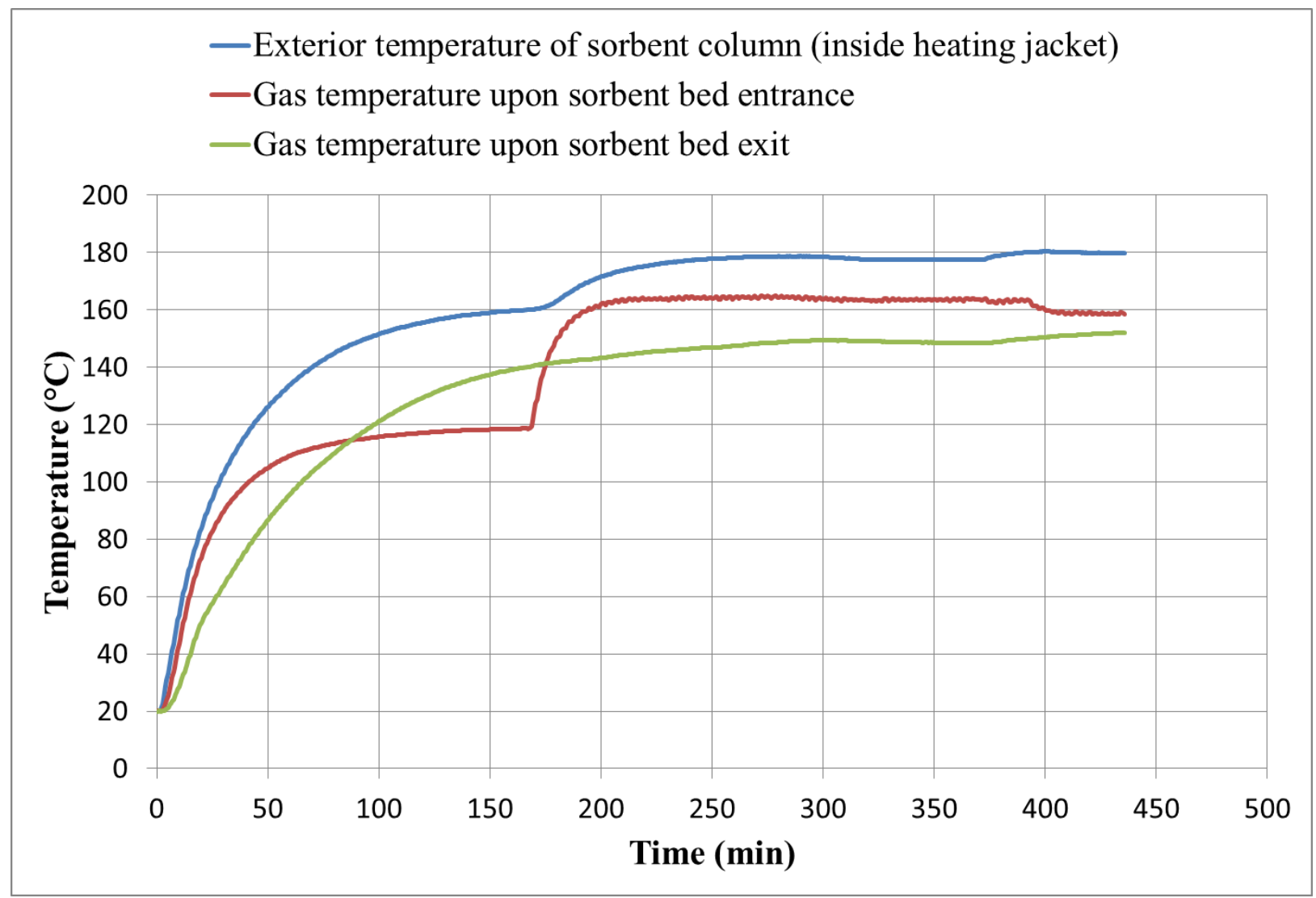

Figure 9: Temperature profile of simplified capture system.

\section{CONCLUSIONS}

A sorbent-based capture system designed for integration into the existing DOG treatment system at the ATALANTE facility has been successfully designed and fabricated and has undergone shakeout testing. Shakeout testing resulted in a simplified system. This system should be easily installed into the existing facility and should be straightforward to operate during future experimental testing. All parts were selected to be compatible with ATALANTE power supplies, space requirements, and the existing DOG treatment system. Additionally, the system was demonstrated to meet all of four design requirements. These include (1) a dissolver off-gas flow rate of $\leq 100 \mathrm{~L} / \mathrm{h}(1.67 \mathrm{~L} / \mathrm{min})$, (2) an external temperature of $\leq 50^{\circ} \mathrm{C}$ for all system components placed in the hot cell, (3) a sorbent bed temperature of $\sim 150^{\circ} \mathrm{C}$, and (4) a gas temperature of $\sim 150^{\circ} \mathrm{C}$ upon entry into the sorbent bed. The system will be ready for shipment and installation in the existing DOG treatment system at ATALANTE. 